\title{
Analisis Likuiditas Saham Sektor Perbankan di BEI Menggunakan Analisis Intervensi dan Autoregressive Conditional Duration
}

\author{
Luh Putu Shintya Handayani ${ }^{(1,2)}$ dan Dedy Dwi Prastyo ${ }^{(1)^{*}}$ \\ ${ }^{(1)}$ Departemen Statistika, Fakultas Sains dan Analitika Data \\ Institut Teknologi Sepuluh Nopember (ITS) \\ Jl. Arief Rahman Hakim, Surabaya 60111 Indonesia \\ ${ }^{(2)}$ Bank Central Asia \\ e-mail:dedy-dp@statistika.its.ac.id ${ }^{(1)^{*}}$; shintyahandayani24@gmail.com ${ }^{(1,2)}$
}

\begin{abstract}
Abstrak-Tax Amnesty merupakan Undang-Undang yang menjadi isu hangat 2016 dan berakhir pada Maret 2017. Kebijakan Tax Amnesty mengharuskan pihak bank menjadi pihak penerima dana repatriasi. Terkait hal itu, berdasarkan isu ekonomi finansial 2015 hingga 2016 terdapat saham bank yang selalu diburu oleh investor karena saham yang likuid. Saham perbankan yang paling dipertimbangkan untuk diperdagangkan yaitu Bank Central Asia (BBCA), Bank Mandiri (BMRI), Bank Rakyat Indonesia (BBRI), dan Bank Negara Indonesia (BBNI) karena masuk dalam kelompok saham LQ45. Tujuan penelitian ini adalah mengetahui gambaran data volume, mengetahui efek adanya intervensi akibat Tax Amnesty, dan mendapat kesimpulan mengenai likuiditas saham sebelum dan selama Tax Amnesty dari model ACD. Model ACD merupakan model alternatif lain di luar intervensi. Analisis intervensi yang dilakukan menunjukkan bahwa terdapat efek intervensi diberlakukannya Tax Amnesty pada volume saham perusahaan BMRI dan BBNI, namun tidak pada BBCA dan BBRI. Model intervensi yang terbentuk belum memenuhi distribusi normal. Model ACD menghasilkan bahwa volume transaksi lebih likuid dilihat dari durasi yang tinggi pada periode Tax Amnesty. Durasi menunjukkan kejadian volume transaksi yang rendah, jadi bila nilai durasi tinggi maka volume transaksi rendah jarang terjadi. Hanya saja, pada saham BBRI tidak dapat dibandingkan sebelum Tax Amnesty dan setelah Tax Amnesty karena data tidak terdapat efek ACD dilihat dari parameter konstanta saja yang signifikan dalam model.
\end{abstract}

Kata Kunci- Autoregressive Conditional Duration, Analisis Likuiditas, Intervensi, Model Error Multiplikatif

\section{PENDAHULUAN}

$\mathrm{D}$ iterapkannya Tax Amnesty akan memberikan dampak pada penerimaan pajak dan arus modal masuk atau capital inflows. Semakin banyak dana yang masuk maka akan mampu meningkatkan pertumbuhan ekonomi yang nantinya melonggarkan likuiditas pada saham perbankan. Didasarkan oleh isu ekonomi finansial di tahun 2015 hingga 2016 terdapat beberapa saham bank yang selalu diburu oleh investor ataupun trader. Pertimbangan pihak investor atau trader memilih saham perbankan adalah saham likuid artinya transaksi jual beli saham yang secara kontinyu dilakukan oleh investor dan trader dengan kata lain demand dan supply selalu tinggi. Selain itu kinerja perbankan yang baik juga mempengaruhi harga per lembar saham di beberapa saham bank tersebut. Berdasarkan data yang diolah infobank saham-saham perbankan yang menduduki peringkat lima besar emiten adalah Bank Central Asia (BBCA), Bank Mandiri (BMRI) dan Bank Rakyat Indonesia (BBRI) [1] Selain ketiga bank tersebut bank yang memiliki peranan besar adalah bank yang masuk dalam BUKU 4. Bank yang termasuk dalam kategori BUKU 4 adalah Bank Central Asia, Bank Mandiri, Bank Rakyat Indonesia, dan Bank Negara Indonesia serta ditambah satu bank lagi yaitu Bank CIMB Niaga per September 2016 [2].

Saham perbankan yang akan dianalisis hanya saham dari empat bank yang dinilai memiliki likuiditas terbaik yaitu Bank Central Asia (BBCA), Bank Mandiri (BMRI), Bank Rakyat Indonesia (BBRI), dan Bank Negara Indonesia (BBNI). Dimana keempat saham tersebut secara stabil periode Februari 2016 sampai Juli 2016 selalu masuk dalam indeks LQ45. LQ45 adalah Indeks Likuiditas Bursa Efek Jakarta [3]. Empat saham perbankan yang diduga paling dipertimbangkan untuk diperdagangkan juga merupakan bank yang ditunjuk untuk menerima dana dari kebijakan Tax Amnesty. Likuiditas berdasarkan volume dianalisis menggunakan Model Error Multiplikatif dengan pendekatan ACD (Autoregressive Conditional Duration). Selain menggunakan metode ACD, alternatif analisis lain adalah intervesi untuk melihat apakah terdapat efek intervensi akibat diberlakukannya kebijakan Tax Amnesty.

Tujuan penelitian ini adalah mendeskripsikan data volume transaksi saham perusahaan sektor perbankan, mengetahui efek Tax Amnesty terhadap volume transaksi dengan analisis intervensi, dan memperoleh kesimpulan mengenai likuiditas saham perbankan sebelum dan selama Tax Amnesty berlangsung dilihat dari model ACD terbaik. Model ACD merupakan model pembanding terlepas dari model intervensi yang terbentuk.

Terkait metode ACD yang digunakan telah terdapat penelitian sejenis berjudul Autoregressive Conditional Duration Models: An Application in the Brazilian Stock Market memberikan gambaran bahwa selama beberapa dekade studi keuangan biasa menggunakan data harian dimana yang biasa menjadi fokusan adalah harga penutupan per hari dan mengabaikan peristiwa intraday [4]. Namun, karena semakin berkembang pesat industri keuangan dan evolusi yang cepat pada optimasi computer sehingga data intraday dapat direkam. Hasil penelitian menunjukkan bahwa model Burr-ACD berisi EACD dan WACD model sebagai kasus khusus yang berguna dalam pemodelan namun model kurang membatasi dan bisa mengambil bentuk yang lebih realistis.

Metode intervensi juga telah banyak digunakan salah satunya adalah Peramalan Nilai Tukar Dolar Amerika Serikat terhadap Rupiah Menggunakan Intervensi dan ANFIS [5]. Penelitian menyimpulkan bahwa pada metode intervensi, nilai 
tukar dollar Amerika Serikat terhadap rupiah dipengaruhi oleh kejadian Pemilihan Umum (Pemilu) Presiden dan pengumuman People Bank of China (PBoC) melakukan devaluasi yuan.

Penelitian sebelumnya yang berkaitan dengan volume saham adalah mengenai Pengaruh Return Saham, Volume Perdagangan dan Volatilitas Harga Saham Terhadap Bid-Ask Spread pada Perusahaan yang Melakukan Stock Split di Bursa Efek Indonesia menghasilkan bahwa return saham, volume perdagangan dan volatilitas harga saham secara serempak berpengaruh signifikan terhadap bid-ask spread pada perusahaan yang melakukan stock split di Bursa Efek [6]. Pada penelitian lainnya diperoleh bahwa terdapat pengaruh yang signifikan antara harga saham, return saham, dan volume perdagangan terhadap likuiditas saham sesudah stock split [7]. Dari kedua penelitian tersebut dapat diketahui bahwa volume transaksi dapat digunakan sebagai salah satu acuan dalam menentukan likuiditas saham.

\section{TINJAUAN PUSTAKA}

\section{A. Volume Transaksi Saham}

Volume transaksi saham mencerminkan kekuatan antara permintaan dan penawaran yang merupakan manivestasi dari tingkah laku investor maupun trader [8]. Volume perdagangan merupakan bagian yang diterima dalam analisis teknikal. Kegiatan perdagangan dalam volume yang sangat tinggi di suatu bursa akan ditafsirkan sebagai tanda pasar akan membaik (bullish).

\section{B. Autoregressive Integrated Moving Average (ARIMA)}

Bentuk umum model ARIMA non musiman adalah sebagai berikut [9].

$$
\phi_{p}(B)(1-B)^{d} V_{t}=\theta_{0}+\theta_{q}(B) a_{t}
$$

dengan,

$V_{t}:$ volume transaksi harian perusahaan emiten

$\phi_{p}:$ koefisien komponen AR non musiman dengan orde $p$

$\theta_{q}:$ koefisien komponen MA non musiman dengan orde $q$

$\phi_{p}(B): 1-\phi_{1} B-\ldots-\phi_{p} B^{p}$

$\theta_{q}(B): 1-\theta_{1} B-\ldots-\theta_{q} B^{q}$

$(1-B)^{d}$ : operator untuk differencing orde $d$

$a$ : nilai residual pada saat $t$

Model umum ARIMA $(p, d, q)$ sebagai berikut.

$$
\left(1-\phi_{1} B-\ldots-\phi_{p} B^{p}\right)(1-B)^{d} V_{t}=\theta_{0}+\left(1-\theta_{1} B-\ldots-\theta_{q} B^{q}\right) a_{t}
$$

C. Analisis Intervensi

Model intervensi merupakan suatu model yang dipergunakan pada saat kejadian khusus diluar perkiraan yang mempengaruhi variabel yang diramalkan. Bentuk umum dari model intervensi multiple intervention inputs adalah sebagai berikut[9].

$$
V_{t}=\sum_{j=1}^{k} \frac{\omega_{j}(B) B^{b_{j}}}{\delta_{j}(B)} I_{j t}+\frac{\theta(B)}{\phi(B)} a_{t}
$$

$I_{j t}$ adalah variabel intervensi (bisa step atau pulse function), $j=1,2, \ldots, k$

$\omega_{j}(B): \omega_{0}-\omega_{1} B-\omega_{2} B^{2}-\ldots-\omega_{s} B^{s}$

$\delta_{j}(B): 1-\delta_{1} B-\delta_{2} B^{2}-\ldots-\delta_{r} B^{r}$

$\frac{\theta(B)}{\phi(B)} a_{t}=N_{t}:$ noise series

$b:$ delay waktu dimana efek intervensi mulai terjadi

$r$ : lamanya pengaruh intervensi

$s$ : pola dari efek intervensi

Secara umum ada dua jenis variabel intervensi, yaitu fungsi step (step function) dan fungsi pulse (pulse function). Intervensi pada waktu $T$ yaitu waktu mulainya terjadi intervensi dan berlanjut pada waktu berikutnya. Pada kondisi ini variabel intervensi merupakan step function secara matematis dapat dinotasikan sebagai berikut.

$$
I_{j t}=S_{t}^{\left(T_{j}\right)}=\left\{\begin{array}{l}
1, t \geq T_{j} \\
0, t<T_{j}
\end{array}\right.
$$

\section{Generalized Autoregressive Conditional Heteroskedasticity}

Model GARCH adalah pengembangan dari model ARCH yang dikenalkan oleh Engle tahun 1982 yang telah berhasil diaplikasikan pada data keuangan dengan adanya volatility cluster. Padahal pemodelan data time series dilakukan berdasarkan asumsi homoskedastisitas pada varian error sehingga pemodelan dengan time series ARIMA saja tidak cukup[10]. Pada kasus heteroskedastisitas, model regresi dapat dituliskan dengan persamaan (5) sebagai berikut.

$$
V_{t}=\mu_{t}+\varepsilon_{t}
$$

Sehingga pada kasus heteroskedastisitas nilai $\varepsilon_{t}$ dapat dimodelkan sesuai persamaan (6) berikut.

$$
\varepsilon_{t}=\sigma_{t} Z_{t}
$$

Nilai $\varepsilon_{t}$ dimodelkan ARCH yang dikembangkan menjadi GARCH untuk menangkap heteroskedastisitas. Persamaan secara umum dari model GARCH dengan order $(r, s)$.

$$
\begin{gathered}
\sigma_{t}^{2}=\omega+\tau_{1} \varepsilon_{t-1}^{2}+\ldots+\tau_{r} \varepsilon_{t-r}^{2}+\beta_{1} \sigma_{t-1}^{2}+\ldots+\beta_{s} \sigma_{t-s}^{2} \\
\sigma_{t}^{2}=\omega+\sum_{i=1}^{r} \tau_{i} \varepsilon_{t-i}^{2}+\sum_{j=1}^{s} \beta_{j} \sigma_{t-j}^{2}
\end{gathered}
$$

dimana $\omega>0, \tau>0$, dan $\beta>0$.

\section{E. Model Autoregressive Conditional Duration}

Model $A C D$ ditentukan oleh kondisi dimana $\psi_{i}$ merupakan ekspektasi bersyarat dari durasi ke- $i$ dengan waktu durasi sebelumnya, yang dinyatakan [10]

$$
\psi_{i}=E\left(x_{i} \mid F_{i-1}\right) .
$$

Sesuai persamaan (8) model umum $A C D$ dapat dituliskan seperti persamaan (9).

$$
x_{i}=\psi_{i} \in_{i}
$$

Model ACD dapat dianggap sebagai model GARCH untuk data durasi.

$$
\psi_{i}=\omega+\sum_{j=1}^{r} \tau_{j} x_{i-j}+\sum_{j=1}^{s} \beta_{j} \psi_{i-j}
$$




\section{F. Perumusan Model Autoregressive Conditional Duration}

Menentukan durasi data terlebih dahulu dihitung nilai residual ARIMA-GARCH. Nilai residual yang lebih kecil dari nol diberi nilai 1 dan yang lebih besar dari nol diberi nilai 0 . Hal ini diambil dari konsep pengelolaan risiko dimana efek negatif lebih memiliki andil dibanding efek positif[10]. Artinya berita buruk pada perusahaam emiten memiliki efek lebih tinggi dibanding berita baik.

Menghitung durasi atau interval antara dua waktu kejadian yaitu $X_{i}=t_{t}-t_{i-1}$, dengan $X_{i}$ adalah durasi ke-i, $t_{i}$ adalah saat kejadian ke-i yang nilai residual yang lebih kecil dari nol [11]. Selanjutnya pemeriksaan efek ACD dari data durasi yang diperoleh. Pemeriksaan efek ACD dengan ACF plot menerangkan bahwa jika tidak ada efek $A C D$ maka ACF dan PACF seharusnya adalah nol pada semua lag atau secara statistik tidak signifikan.

Data durasi diuji distribusinya dengan hipotesis:

$\mathrm{H}_{0}$ : data durasi bersifat memory less (berdistribusi eksponensial) sehingga $\lambda=1$

$\mathrm{H}_{1}$ : data durasi tidak bersifat memory less (berdistribusi weibull sehingga $\lambda \neq 1$

Berdasarkan hipotesis nol didapat distribusi durasi yang digunakan adalah:

$$
f_{\text {exp }}=(x, \lambda)=\lambda \exp (-\lambda x)
$$

dimana eksponensial memiliki hazard function sesuai persamaan:

$$
\lambda_{\text {exp }}(x)=\frac{f_{\text {exp }}(x)}{1-F_{\text {exp }}(x)}=\lambda
$$

Menguji independensi secara statistik harus membuat alternatif yang dapat menunjukkan dependensi durasi dengan mengikuti distribusi weibull yang dapat dituliskan seperti persamaan (13)

$$
f_{w}=(x, \gamma, \lambda)=\gamma^{\lambda} \gamma x^{\lambda-1} \exp \left(-(\gamma x)^{\lambda}\right)
$$

Setelah diperoleh model maka pemeriksaan diagnostik dilakukan untuk mengetahui apakah data time series tersebut masih mengandung autokorelasi atau tidak. Pengujian asumsi white noise dilakukan dengan menggunakan uji Ljung Box yang didasarkan pada nilai ACF dengan hipotesis sebagai berikut.

$\mathrm{H}_{0}: \rho_{1}=\rho_{2}=\ldots=\rho_{K}=0$ (residual white noise)

$\mathrm{H}_{1}$ : minimal ada satu $\rho_{k} \neq 0$ dengan $k=1,2,3, \ldots, K$ (residual tidak white noise)

Statistik uji yang digunakan pada pengujian ini ditulis sesuai persamaan (14) dengan $n$ adalah banyaknya data, $k$ adalah lag waktu, dan $\hat{\rho}_{k}^{2}$ adalah nilai autokorelasi lag ke-k dari deret waktu.

$$
Q=n(n+2) \sum_{k=1}^{K} \frac{\hat{\rho}_{k}^{2}}{(n-k)}
$$

Nilai $Q$ dibandingkan dengan nilai tabel $\chi_{\alpha, d b}^{2} . \mathrm{H}_{0}$ ditolak jika $Q>\chi_{\alpha, d b}^{2}$ yang menunjukkan bahwa residual tidak memenuhi asumsi white noise (9).

\section{G. $\quad$ Kriteria Pemilihan Model Terbaik}

Terdapat dua kriteria yang digunakan sebagai alternatif memilih model yaitu AIC (Akaike's Information Criterion) dan
SBC (Schwarz's Bayesian Criterion) [12]. Kriteria pemilihan model ini berdasarkan kemungkinan log. AIC ditulis pada persamaan (15) .

$$
A I C=-2 \log (L)+2(p+q)
$$

dengan $p$ dan $q$ adalah jumlah parameter dalam model dan $L$ adalah kemungkinan yang telah dievaluasi pada MLE serta $n$ adalah jumlah periode waktu (jumlah data). Model $S B C$ dapat ditulis sesuai persamaan (16).

$$
S B C=-2 \log (L)+\log (n)(p+q)
$$

\section{METODOLOGI PENELITIAN}

\section{A. Sumber Data dan Variabel Penelitian}

Data yang digunakan dalam penelitian ini adalah data sekunder yang diperoleh dari finance.yahoo.com. Data volume transaksi saham perusahaan sektor perbankan yang memiliki kapital besar yaitu Bank Central Asia $\mathrm{V}_{1, \mathrm{t}}$ dengan kode emiten BBCA, Bank Mandiri $V_{2, t}$ dengan kode emiten BMRI, Bank Rakyat Indonesia $V_{3, t}$ dengan kote emiten BBRI, dan Bank Negara Indonesia $\mathrm{V}_{4, \mathrm{t}}$ dengan kote emiten BBNI.

Dummy untuk menghitung durasi dilakukan dengan mengkoding data menjadi nilai 0 dan 1 . Nilai 0 jika nilai residual model ARMA-GARCH lebih besar dari nol.

$$
D_{m, t}=\left\{\begin{array}{l}
1, \text { jika residual ARMA-GARCH }<0 \\
0, \text { jika residual ARMA-GARCH } \geq 0
\end{array}\right.
$$

Untuk analisis intervensi periode intervensi yang digunakan adalah selama Tax Amnesty berlangsung yaitu 1 Juli 2016 - 31 Maret 2017.

\section{B. Langkah Analisis}

Langkah yang dilakukan untuk menganalisis adalah sebagai berikut :

a. Download di situs finance.yahoo.com dengan memasukkan kode perusahaan emiten.

b. Melakukan analisis eksplorasi data volume transaksi saham Bank Central Asia, Bank Mandiri, Bank Rakyat Indonesia, dan Bank Negara Indonesia

c. Menggambarkan data volume transaksi saham dengan time series plot.

d. Melakukan pemodelan analisis intervensi untuk data volume transaksi saham.

e. Melakukan pemodelan ARMA-GARCH dan residualnya digunakan untuk menentukan durasi pada transaksi volume saham.

f. Menghitung durasi saham Bank Central Asia, Bank Mandiri, Bank Rakyat Indonesia, dan Bank Negara Indonesia.

g. Melakukan pengujian distribusi durasi data masingmasing perusahaan

h. Memodelkan durasi dari volume transaksi saham Bank Central Asia, Bank Mandiri, Bank Rakyat Indonesia, dan Bank Negara Indonesia dengan menggunakan Model ACD baik Eksponensial ACD atau Weibull ACD.

\section{ANALISIS DAN PEMBAHASAN}

\section{A. Deskripsi Volume Transaksi Saham}

Analisis deskriptif data volume transaksi saham dilakukan untuk mengetahui karakteristik volume transaksi saham 
perusahaan BBCA, BMRI, BBRI, dan BBNI. Deskripsi data volume dapat dilihat secara visual dalam gambar 1. Serta perhitungan statistik deskriptif volume keempat perusahaan sesuai tabel 1 dan tabel 2. Dilihat secara visual rentang boxplot BBCA lebih kecil dibanding tiga saham lain, yang artinya volatilitas tansaksi saham BBCA lebih rendah dibanding tiga saham yaitu BMRI, BBRI, dan BBNI. Outlier pada volume transaksi saham menunjukan bahwa banyak volume transaksi saham bernilai lebih besar dari batas atas. Nilai batas atas volume transaksi saham harian BBCA, BMRI, BBRI, dan BBNI berturut-turut sebesar 29542400, 61016000, 67932500, 58971700.

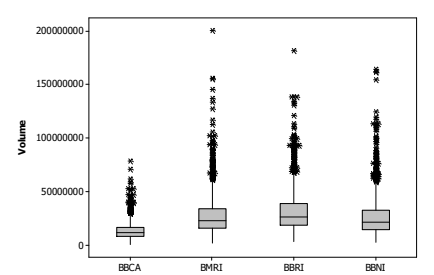

Gambar 1 Boxplot Volume Transaksi Saham

Tabel 1 menunjukkan bahwa volume transaksi perusahaan BBRI paling tinggi dibanding BBCA, BMRI, dan BBNI. Dilihat dari koefisien varians volume transaksi terendah, diketahui bahwa transaksi perusahaan BBCA lebih stabil dilihat dari koefisien vasiansi volume transaksi saham harian senilai 60,17 dibanding tiga perusahaan lainnya. Data volume transaksi secara keselurusan menunjukan bahwa data tidak mengikuti distribusi normal karena nilai skewness tidak sama dengan nol dan nilai kurtosis tidak sama dengan tiga.

$$
\text { Tabel } 1
$$

Karakteristik Volume Transaksi Saham

\begin{tabular}{llllll}
\multicolumn{7}{c}{ Karakteristik Volume Transaksi Saham } \\
\hline Baham & Rata-rata & Std. Dev & Koef. Var & Skew. & Kurt. \\
\hline BMRI & 13713658 & 8252129 & 60,17 & 1,95 & 6,61 \\
BBRI & 27690499 & 18014663 & 66,19 & 2,45 & 10,72 \\
BBNI & 26125793772 & 19208546 & 60,99 & 1,99 & 6,12 \\
\hline
\end{tabular}

Tabel 2

Karakteristik Volume Transaksi Saham Per Periode

\begin{tabular}{|c|c|c|c|c|c|c|}
\hline & Saham & Rata-rata & Std.Dev & $\begin{array}{c}\text { Koef. } \\
\text { Var }\end{array}$ & Skew & Kurt. \\
\hline \multirow{4}{*}{ 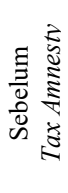 } & BBCA & 13085600 & 7860985 & 60,07 & 2,19 & 8,88 \\
\hline & BMRI & 28349462 & 18734036 & 66,08 & 2,45 & 10,58 \\
\hline & BBRI & 32478421 & 19615150 & 60,39 & 1,95 & 5,86 \\
\hline & BBNI & 26304752 & 18274259 & 69,47 & 2,52 & 10,54 \\
\hline \multirow{4}{*}{ 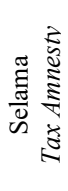 } & BBCA & 19141873 & 9493288 & 49,59 & 0,88 & 0,38 \\
\hline & BMRI & 21995176 & 13073198 & 59,44 & 1,50 & 2,17 \\
\hline & BBRI & 22983596 & 12352717 & 53,75 & 1,87 & 4,07 \\
\hline & BBNI & 24579099 & 15547367 & 63,25 & 1,42 & 2,07 \\
\hline
\end{tabular}

Tabel 2 menunjukkan bahwa saham yang paling tidak stabil dalam transaksi harian yaitu BBNI baik selama periode Tax Amnesty maupun selama periode sebelum Tax Amnesty dilihat dari nilai koefisien variansi tertinggi yaitu 69,47 dan 63,25 . Volume transaksi harian saham BBCA, BMRI, BBRI, dan BBNI sebelum dan selama Tax Amnesty tidak mengikuti distribusi normal karena nilai skewness tidak sama dengan nol dan nilai kurtosis tidak sama dengan tiga. Lonjakan volume transaksi pada masa sebelum Tax Amnesty menyebabkan ratarata volume transaksi lebih tinggi pada periode sebelum Tax Amnesty dibandingkan pada periode selama Tax Amnesty berlangsung.

\section{B. Pemodelan Volume Transaksi Saham dengan Intervensi}

Tahapan identifikasi model ARIMA mengharuskan bahwa data yang dimodelkan merupakan data yang telah stasioner dalam mean dan varians. Pola volume transaksi sebelum dan selama Tax Amnesty digambarkan dalam time series plot menunjukkan data tidak stasioner dalam mean dan varians, maka dilakukan transformasi dengan lamda 0,14 untuk BBCA dan transformasi ln untuk tiga perusahaan lainnya karena nilai lamda 0. Box-Cox plot BBCA dapat dilihat pada gambar 3. Setelah ditransformasi ternyata belum stasioner dalam mean sehingga dilakukan differenching 1 sehingga diperoleh ACF dan PACF plot seperti gambar 4 untuk membentuk model dugaan pada perusahaan $\mathrm{BBCA}$.

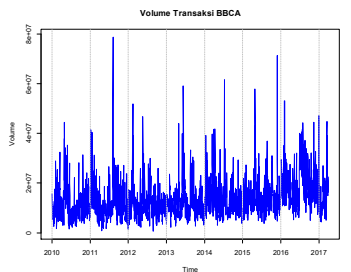

(a)

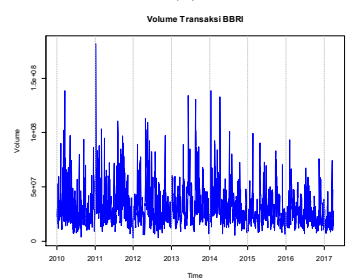

(c)

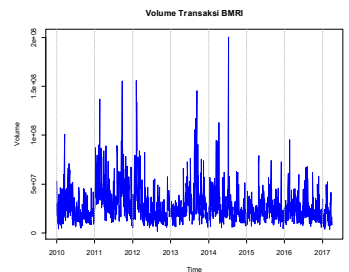

(b)

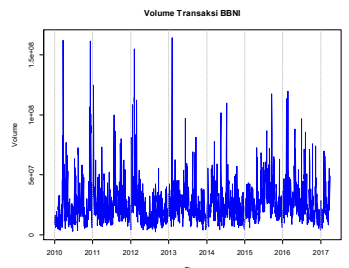

(d)
Gambar 2 Time Series Plot Volume Transaksi Saham (a) BBCA, (b) BMRI, (c) BBRI, dan (d) BBNI

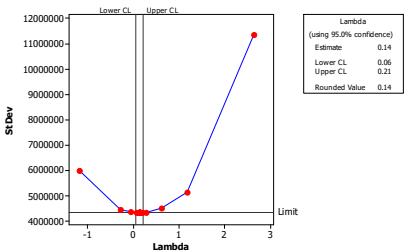

(a)

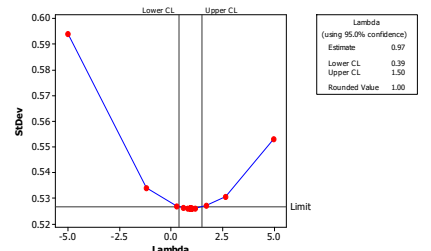

(b)
Gambar 3 Box-cox Plot BBCA (a) Data Volume, (b) Data Transformasi

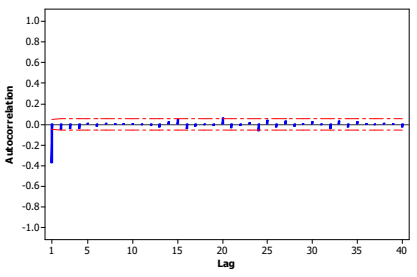

(a)

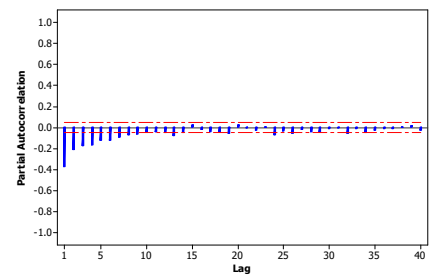

(b)
Gambar 4 (a) ACF dan (b) PACF Plot Volume BBCA 
Tabel 3

Estimasi dan Uji Signifikansi Parameter Model ARIMA

\begin{tabular}{|c|c|c|c|c|c|c|}
\hline Saham & Model & \multicolumn{2}{|c|}{ Parameter } & Estimasi & $\mathbf{t}_{\text {hitung }}$ & P-value \\
\hline \multirow{5}{*}{ BBCA } & \multirow{5}{*}{ 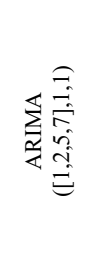 } & \multicolumn{2}{|c|}{$\phi_{1}$} & 0,380 & 15,58 & $<0,0001$ \\
\hline & & \multicolumn{2}{|c|}{$\phi_{2}$} & 0,116 & 4,70 & $<0,0001$ \\
\hline & & \multicolumn{2}{|c|}{$\phi_{5}$} & 0,064 & 2,73 & 0,0064 \\
\hline & & \multicolumn{2}{|c|}{$\phi_{7}$} & 0,062 & 2,568 & 0,0074 \\
\hline & & \multicolumn{2}{|c|}{$\theta_{1}$} & 0,991 & 287,09 & $<0,0001$ \\
\hline \multirow{4}{*}{ BMRI } & \multirow{4}{*}{ 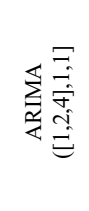 } & \multicolumn{2}{|c|}{$\phi_{1}$} & 0,387 & 14,35 & $<0,0001$ \\
\hline & & \multicolumn{2}{|c|}{$\phi_{2}$} & 0,057 & 2,18 & 0,0297 \\
\hline & & \multicolumn{2}{|c|}{$\phi_{4}$} & 0,061 & 2,41 & 0,0160 \\
\hline & & \multicolumn{2}{|c|}{$\theta_{1}$} & 0,947 & 86,85 & $<0,0001$ \\
\hline \multirow{3}{*}{ BBRI } & \multirow{3}{*}{$\underset{\substack{a \\
\mathbb{a}}}{=}=$} & \multicolumn{2}{|c|}{$\phi_{1}$} & 0,451 & 18,59 & $<0,0001$ \\
\hline & & \multicolumn{2}{|c|}{$\phi_{2}$} & 0,149 & 6,18 & $<0,0001$ \\
\hline & & \multicolumn{2}{|c|}{$\theta_{1}$} & 0,994 & 377,97 & $<0,0001$ \\
\hline \multirow{4}{*}{ BBNI } & & \multicolumn{2}{|c|}{$\phi_{1}$} & 1,259 & 19,59 & $<0,0001$ \\
\hline & 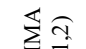 & \multicolumn{2}{|c|}{$\phi_{2}$} & $-0,309$ & $-6,70$ & $<0,0001$ \\
\hline & 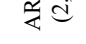 & \multicolumn{2}{|c|}{$\theta_{1}$} & 1,801 & 32,42 & $<0,0001$ \\
\hline & & \multicolumn{2}{|c|}{$\theta_{2}$} & $-0,803$ & $-14,60$ & $<0,0001$ \\
\hline \multicolumn{7}{|c|}{$\begin{array}{c}\text { Tabel } 4 \\
\text { Diagnosa Model ARIMA }\end{array}$} \\
\hline \multirow[t]{2}{*}{ Model } & & $\begin{array}{r}\mathbf{U} \\
\text { White }\end{array}$ & toise & & & $\begin{array}{l}\text { ji } \\
\text { ggorov } \\
\text { rnov }\end{array}$ \\
\hline & Lag & $\chi_{\text {hitung }}^{2}$ & db & $\chi_{0,05, d b}^{2}$ & D $_{\text {hit }}$ & P-value \\
\hline & 6 & 1,67 & 1 & 11,070 & & \\
\hline$\varangle=$ & 12 & 5,07 & 7 & 14,067 & & \\
\hline in & 18 & 14,74 & 13 & 22,362 & 0,036 & $<0,01$ \\
\hline i & 24 & 26,68 & 19 & 30,144 & & \\
\hline 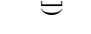 & 30 & 29,76 & 25 & 37,652 & & \\
\hline & 6 & 2,55 & 2 & 5,991 & & \\
\hline$<=$ & 12 & 6,96 & 8 & 15,507 & & \\
\hline$\sum \vec{\sigma}$ & 18 & 14,77 & 14 & 23,685 & 0,027 & $<0,01$ \\
\hline वृ & 24 & 23,14 & 20 & 31,410 & 0,021 & 0,01 \\
\hline 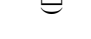 & 30 & 33,40 & 26 & 38,885 & & \\
\hline & 6 & 5,12 & 3 & 7,815 & & \\
\hline$\overleftrightarrow{\Xi}$ & 12 & 10,18 & 9 & 16,919 & & \\
\hline$\Rightarrow=$ & 18 & 18,01 & 15 & 24,996 & 0,034 & $<0,01$ \\
\hline & 24 & 23,37 & 21 & 32,671 & & \\
\hline & 30 & 28,11 & 27 & 40,113 & & \\
\hline & 6 & 2,35 & 2 & 5,991 & & \\
\hline & 12 & 6,10 & 8 & 15,507 & & \\
\hline$\leq$ & 18 & 9,45 & 14 & 23,685 & 0,029 & $<0,01$ \\
\hline 4 & 24 & 13,45 & 20 & 31,410 & & \\
\hline & 30 & 21,67 & 26 & 38,885 & & \\
\hline
\end{tabular}

Langkah yang sama dilakukan pada tiga perusahaan lainnya. Sehingga hasil estimasi dan uji signifikansi model pada masing masing perusahaan sesuai tabel 3. Model pada tabel 3 merupakan model yang telah signifikan dan terbaik yang dipilih dari nilai AIC dan SBC terendah.

Model ARIMA ([1,2,5,7],1,1) volume transaksi saham BBCA secara matematis dapat ditulisakan sebagai berikut.

$$
\hat{V}_{t}=\frac{(1-0,99116 B) a_{t}}{\left(1-0,38076 B-0,11587 B^{2}-0,06359 B^{5}-0,06213 B^{7}\right)(1-B)}
$$

Model yang telah signifikan diuji diagnosa residual meliputi uji white noise dan uji residual berdistribusi normal.
Tabel 4 menunjukkan bahwa asumsi white noise pada model ARIMA sudah terpenuhi. Namun, model terbaik masingmasing perusahaan masih belum memenuhi asumsi distribusi normal.

Selanjutnya dilakukan pemodelan intervensi pada data volume transaksi. Orde intervensi diperoleh dengan melihat diagram residual. Diagram residual pada gambar 5 diketahui bahwa Tax Amnesty menyebabkan response impulse keluar dari batas $\pm 2 \sigma$. Oleh karena itu terdapat model intervensi yang dapat terbentuk untuk volume transaksi perusahaan BBCA, BBRI, dan BMRI, dan BBNI.

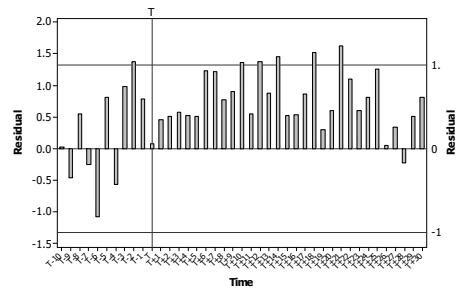

(a)

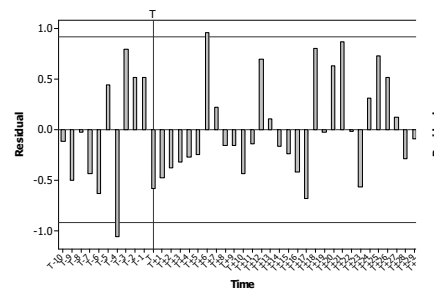

(c)

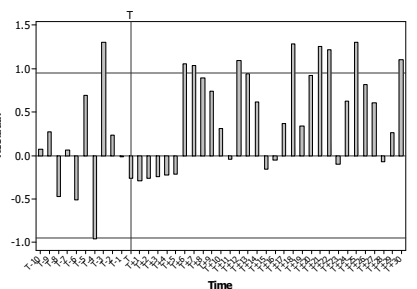

(b)

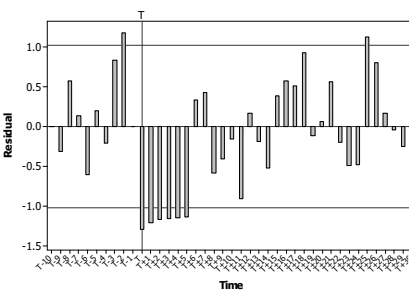

(d)
Gambar 5 Diagram Residual Terhadap T Intervensi (a) BBCA, (b) BMRI, (c) BBRI, dan (d) BBNI

Pemodelan intervensi BBCA berdasarkan batas terlihat lag yang pertama kali keluar adalah lag ke $\mathrm{T}+10$ selanjutnya $\mathrm{T}+12$ dan $\mathrm{T}+14$. Sehingga ditentukan dugaan orde intervensi yaitu $b=10, r=1, s=0$. Hasil pengujian signifikansi parameter menunjukkan model intervensi tidak signifikan.

Orde intervensi BMRI yaitu $b=6, r=0, s=0$. Orde intervensi akan digunakan dalam pemodelan intervensi. Nilai $b=6$ dilihat dari orde pertama yang signifikan yaitu saat $T+6$ parameter ARIMA dan parameter interevensi signifikan. Model intervensi secara matematis dapat ditulis sebagai berikut.

$\hat{V}_{t}=\left(0,64585 B^{6}\right) S_{t}^{1695}+\frac{(1-0,95889 B) a_{t}}{\left(1-0,39771 B-0,04830 B^{2}-0,08059 B^{4}\right)(1-B)}$

Orde intervensi yaitu $b=6, r=0, s=0$ untuk volume transaksi BBRI. Namun, parameter intervensi BBRI juga tidak signifikan sama halnya dengan BBCA. Selanjutnya pemodelan intervensi untuk BBNI. response impulse pada $\mathrm{T}$ sampai $\mathrm{T}+5$ keluar dari batas $\pm 2 \sigma$. Oleh karena itu orde intervensi yaitu $b=0, r=0, s=0$. Volume transaksi BBNI sebelum dan selama Tax Amnesty menunjukkan bahwa terdapat efek intervensi karena hasil uji signifikansi parameter model intervensi signifikan. Model intervensi dapat ditulis dalam persamaan seperti:

$$
\hat{V}_{t}=(-0,50251) S_{t}^{1695}+\frac{\left(1-1,77758 B+0,78010 B^{2}\right) a_{t}}{\left(1-1,23598 B+0,29293 B^{2}\right)(1-B)}
$$

Model intervensi yang terbentuk telah memenuhi asumsi white noise namun belum memenuhi asumsi distribusi normal. 
Keseluruhan hasil estimasi parameter model intervensi dapat dilihat pada Lampiran.

\section{Pemodelan Durasi dengan ACD}

Data volume transaksi saham sektor perbankan yang telah dimodelkan dengan intervensi belum memenuhi distribusi normal. Oleh karena itu, dilakukan pemodelan dengan Autoregressive Conditional Duration (ACD). Model ACD yang digunakan adalah model dengan distribusi eksponensial dan weibull. Pemodelan ACD dilakukan sebagai model pembanding dari analisis intervensi. Sebelum memperoleh data durasi, terlebih dahulu volume transaksi saham dimodelkan dengan ARMA-GARCH. Data yang dimodelkan ARMA-GARCH adalah volume yang telah stasioner dalam mean dan varians.

Tabel 5

Estimasi Parameter ARMA-GARCH Sebelum Tax Amnesty

\begin{tabular}{|c|c|c|c|c|c|}
\hline Saham & Model & Parameter & Estimasi & $\mathbf{t}_{\text {hitung }}$ & P-value \\
\hline \multirow{5}{*}{ BBCA } & \multirow{5}{*}{ 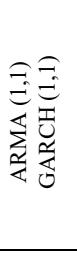 } & $\phi_{1}$ & 0,346119 & 7,6468 & $<0,0001$ \\
\hline & & $\theta_{1}$ & $-0,927441$ & $-31,2292$ & $<0,0001$ \\
\hline & & $\omega$ & 0,009338 & 6,8134 & $<0,0001$ \\
\hline & & $\tau_{1}$ & 0,085517 & 2,5939 & 0,00949 \\
\hline & & $\beta_{1}$ & 0,905537 & 27,3163 & $<0,0001$ \\
\hline \multirow{5}{*}{ BMRI } & \multirow{5}{*}{ 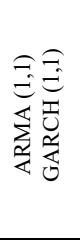 } & $\phi_{1}$ & 0,353677 & 10,6785 & $<0,0001$ \\
\hline & & $\theta_{1}$ & $-0,911161$ & $-53,9094$ & $<0,0001$ \\
\hline & & $\omega$ & 0,004141 & 2,2673 & 0,023373 \\
\hline & & $\tau_{1}$ & 0,087701 & 3,2028 & 0,001361 \\
\hline & & $\beta_{1}$ & 0,904372 & 35,9646 & $<0,0001$ \\
\hline \multirow{5}{*}{ BBRI } & \multirow{5}{*}{ 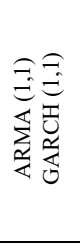 } & $\phi_{1}$ & 0,529778 & 25,2912 & $<0,0001$ \\
\hline & & $\theta_{1}$ & $-0,986617$ & $-4898,1831$ & $<0,0001$ \\
\hline & & $\omega$ & 0,003910 & 3,9207 & $<0,0001$ \\
\hline & & $\tau_{1}$ & 0,017505 & 5,3784 & $<0,0001$ \\
\hline & & $\beta_{1}$ & 0,964194 & 270,2276 & $<0,0001$ \\
\hline \multirow{4}{*}{ BBNI } & \multirow{4}{*}{ 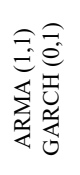 } & $\phi_{1}$ & 0,406045 & 13,458 & $<0,0001$ \\
\hline & & $\theta_{1}$ & $-0,926244$ & $-60,820$ & $<0,0001$ \\
\hline & & $\omega$ & 0,001145 & 21,067 & $<0,0001$ \\
\hline & & $\beta_{1}$ & 0,995380 & 5588,425 & $<0,0001$ \\
\hline
\end{tabular}

Dugaan model ARMA diperoleh dari plot ACF dan PACF. Namun, dalam penelitian ini akan ditetapkan model ARMA yang didasarkan pada prinsip parcimony karena bila menggunakan model sesuai lag signifikan terlalu rumit dan packages syntax yang disediakan $\mathrm{R}$ tidak dapat digunakan. Terdapat tiga model ARMA dugaan yang ditetapkan yaitu $\operatorname{ARMA}(1,1), \operatorname{ARMA}(1,0)$, da $\operatorname{ARMA}(0,1)$. Hal yang sama juga digunakan dalam pemodelan GARCH dimana terdapat tiga model GARCH yang diduga yaitu GARCH $(1,1)$, GARCH $(1,0)$, da GARCH $(0,1)$.

Pemodelan ARMA-GARCH data sebelum dan selama Tax Amnesty dapat dilihat pada tabel 5 dan tabel 6. Diketahui bahwa pada saham BBCA, BMRI, BBRI, dan BBNI memiliki parameter model ARMA-GARCH yang telah signifikan pada taraf $10 \%$. Residual model yang lebih kecil dari nol bernilai 1 dan yang lebih besar dari nol diberi nilai 0 . Hal ini dilakukan untuk menghitung durasi yang digunakan dalam pemodelan ACD.

Tabel 6

Estimasi Parameter ARMA-GARCH Selama Tax Amnesty

\begin{tabular}{|c|c|c|c|c|c|}
\hline Saham & Model & Parameter & Estimasi & thitung $_{\text {hing }}$ & P-value \\
\hline \multirow{3}{*}{ BBCA } & \multirow{3}{*}{ 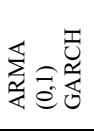 } & $\theta_{1}$ & $-0,72897$ & $-10,2423$ & \\
\hline & & $\omega$ & 0,29951 & 6,9819 & $<0,0001$ \\
\hline & & $\tau_{1}$ & 0,22976 & 2,0738 & 0,038099 \\
\hline \multirow{4}{*}{ BMRI } & \multirow{4}{*}{ 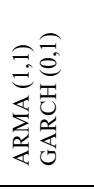 } & $\phi_{1}$ & 0,441860 & 4,5712 & $<0,0001$ \\
\hline & & $\theta_{1}$ & $-0,944891$ & $-18,0404$ & $<0,0001$ \\
\hline & & $\omega$ & 0,000975 & 1,9963 & 0,045905 \\
\hline & & $\beta_{1}$ & 0,995875 & 460,1206 & $<0,0001$ \\
\hline \multirow{4}{*}{ BBRI } & \multirow{4}{*}{ 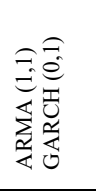 } & $\phi_{1}$ & 0,404029 & 6,1205 & $<0,0001$ \\
\hline & & $\theta_{1}$ & $-0,974910$ & $-228,2920$ & $<0,0001$ \\
\hline & & $\omega$ & 0,000767 & 5,8605 & $<0,0001$ \\
\hline & & $\beta_{1}$ & 0,995750 & 1224,2531 & $<0,0001$ \\
\hline \multirow{4}{*}{ BBNI } & \multirow{4}{*}{ 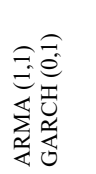 } & $\phi_{1}$ & 0,265866 & 2,0692 & 0,038527 \\
\hline & & $\theta_{1}$ & $-0,772434$ & 0,092929 & $<0,0001$ \\
\hline & & $\omega$ & 0,001052 & 0,000612 & 0,085515 \\
\hline & & $\beta_{1}$ & 0,995535 & 0,002395 & $<0,0001$ \\
\hline
\end{tabular}

Setelah dilakukan perhitungan durasi dari residual model ARMA-GARCH maka data durasi terlebih dahulu diuji distribusi. Uji distribusi yang dilakukan adalah uji distribusi data memenuhi distribusi eksponensial atau weibull. Hasil menunjukkan bahwa data sebelum dan selama Tax Amnesty di semua perusahaan memenuhi ditribusi eksponensial. Namun, dalam penelitian ini tetap dilakukan pemodelan dengan distribusi weibull sehingga dapat dibandingkan model terbaik yang diperoleh.

Data durasi hasil residual model ARMA-GARCH kemudian diperiksa efek ACD sebelum data dimodelkan. Pemeriksaan efek ACD dilihat pada plot ACF dari data durasi. ACF plot pada masing-masing saham menunjukkan bahwa secara visual data durasi saham BBCA, BMRI, BBRI dan BBNI sebelum Tax Amnesty dan selama Tax Amnesty memiliki efek ACD.
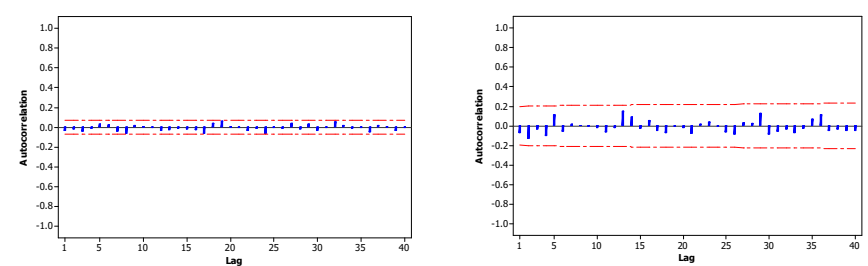

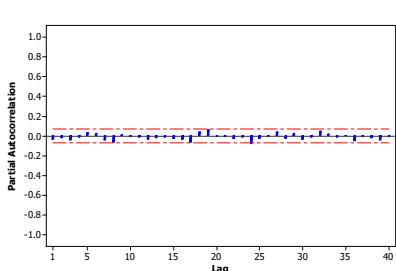

(a)

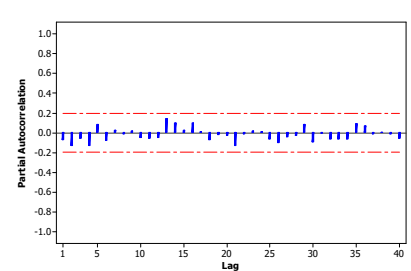

(b)
Gambar 6 ACF dan PACF Data Durasi Kuadrat BBCA (a) Sebelum, (b) Selama

Sebelum melakukan estimasi parameter, terlebih dahulu dilakukan identifikasi model ACD menggunakan plot ACF dan 
PACF dari durasi kuadrat. ACF dan PACF gambar 6 menunjukkan bahwa terdapat lag di data durasi kuadrat saham BBCA sebelum Tax Amnesty mengalami cut off pada lag 24, walaupun plot ACF dan PACF data selama Tax Amnesty tidak semua mengalami cut off. Pemodelan ACD juga menggunakan prinsip parcimony.

Tabel 7

Estimasi dan Uji Signifikansi Parameter ACD Sebelum Tax Amnesty

\begin{tabular}{cccrr}
\hline Saham & Model & Parameter & Estimasi & P-value \\
\hline \multirow{3}{*}{ BBCA } & \multirow{2}{*}{ WACD $(1,1)$} & $\tau_{1}$ & $-0,0398$ & 0,001 \\
& & $\beta_{1}$ & 0,9784 & $<0,0001$ \\
& & $\gamma$ & 1,5493 & $<0,0001$ \\
\hline \multirow{3}{*}{ BMRI } & \multirow{2}{*}{ WACD $(1,1)$} & $\tau_{1}$ & $-0,0162$ & 0,001 \\
& & $\beta_{1}$ & 1,0057 & $<0,0001$ \\
& & $\gamma$ & 1,5352 & $<0,0001$ \\
\hline \multirow{2}{*}{ BBRI } & \multirow{2}{*}{ WACD $(0,0)$} & $\omega$ & 1,98 & $<0,0001$ \\
& & $\gamma$ & 1,51 & $<0,0001$ \\
\hline \multirow{2}{*}{ BBNI } & \multirow{2}{*}{ WACD $(1,1)$} & $\omega$ & 0,0920 & 0,011 \\
& & $\tau_{1}$ & $-0,0273$ & 0,004 \\
& & $\gamma$ & 0,9804 & $<0,0001$ \\
& & $\gamma$ & 1,5492 & $<0,0001$ \\
\hline
\end{tabular}

Model ACD dugaan adalah ACD $(1,1)$, ACD $(1,0)$, dan ACD $(0,1)$. Model ACD yang dibentuk mengikuti distribusi eksponensial dan weibull. Hasil pengujian signifikansi parameter disajikan pada tabel 7 dan tabel 8 diketahui bahwa model WACD dan EACD dari data sebelum Tax Amnesty dan model selama Tax Amnesty memiliki nilai P-value lebih kecil dari taraf signifikan $10 \%$. Hal ini berarti nilai parameter model telah signifikan. Model ini adalah model terbaik dari kriteria kebaikan model.

Tabel 8

\begin{tabular}{|c|c|c|c|c|}
\hline Saham & Model & Parameter & Estimasi & P-value \\
\hline \multirow{4}{*}{ BBCA } & \multirow{4}{*}{ WACD $(1,1)$} & $\omega$ & 0,662 & 0,011 \\
\hline & & $\tau_{1}$ & $-0,203$ & $<0,0001$ \\
\hline & & $\beta_{1}$ & 0,856 & $<0,0001$ \\
\hline & & $\gamma$ & 1,616 & $<0,0001$ \\
\hline \multirow{4}{*}{ BMRI } & \multirow{4}{*}{ WACD $(1,1)$} & $\omega$ & 0,0542 & 0,024 \\
\hline & & $\tau_{1}$ & $-0,0985$ & $<0,0001$ \\
\hline & & $\beta_{1}$ & 1,0776 & $<0,0001$ \\
\hline & & $\gamma$ & 1,7009 & $<0,0001$ \\
\hline \multirow{3}{*}{ BBRI } & \multirow{3}{*}{ WACD $(1,0)$} & $\omega$ & 2,452 & $<0,0001$ \\
\hline & & $\tau_{1}$ & $-0,163$ & 0,067 \\
\hline & & $\gamma$ & 2,126 & $<0,0001$ \\
\hline \multirow{4}{*}{ BBNI } & \multirow{4}{*}{ WACD $(1,1)$} & $\omega$ & 0,399 & $<0,0001$ \\
\hline & & $\tau_{1}$ & $-0,281$ & $<0,0001$ \\
\hline & & $\beta_{1}$ & 1,079 & $<0,0001$ \\
\hline & & $\gamma$ & 1,959 & $<0,0001$ \\
\hline
\end{tabular}

Model WACD $(1,1)$ dari durasi volume transaksi saham BBCA sebelum Tax Amnesty adalah:

$\mathrm{WACD}(1,1): x_{i}=\psi_{i} \in_{i}, \psi_{i}=0,1229-0,0398 x_{i-1}+0,9784 \psi_{i-1}$ dan selama Tax Amnesty adalah sebagai berikut.

WACD $(1,1): x_{i}=\psi_{i} \in_{i}, \psi_{i}=0,662-0,203 x_{i-1}+0,856 \psi_{i-1}$

Model matematis untuk BMRI, BBRI, dan BBNI dapat ditulis dengan cara yang sama seperti BBCA hanya disesuaikan hasil estimasi parameter masing-masing perusahaan. Hasil dari model terbaik yang terbentuk digunakan untuk mengestimasi nilai durasi taksiran. Durasi taksiran dari model sebelum Tax Amnesty ditunjukkan pada gambar 5 sampai gambar 7 disebelah kiri garis merah. Durasi taksiran selama Tax Amnesty dapat digambarkan seperti di dalam batas garis merah.

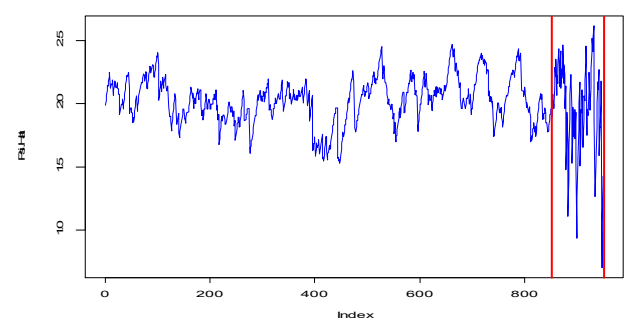

Gambar 7 Durasi Taksiran Model ACD BBCA

Gambar 7 menjelaskan bahwa selama periode sebelum Tax Amnesty durasi BBCA berada pada rentang 1,5 sampai 2,5 yang artinya likuiditas saham relatif stagnan. Periode awal Tax Amnesty durasi tinggi sering terjadi dan pada pertengahan likuiditas sempat turun drastis. Namun, di akhir periode nilai durasi meningkat yang artinya saham semakin liukuid. Tax amnesty mengakibatkan likuiditas saham BBCA menjadi lebih fluktuatif.

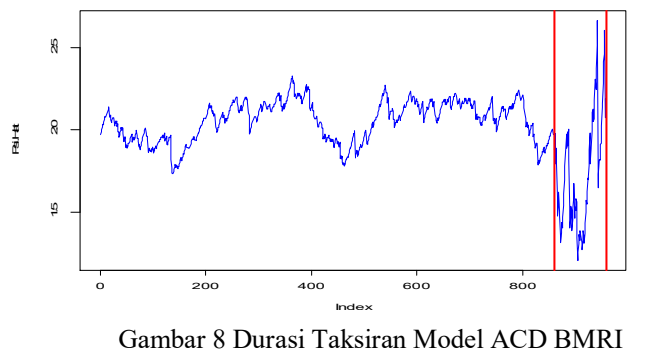

Gambar 8 menjelaskan bahwa selama periode sebelum Tax Amnesty durasi BMRI menggambarkan likuditas saham berada di sekitar 2,0. Pada periode awal Tax Amnesty likuiditas saham BMRI menurun namun, menjelang penutupan Tax Amnesty nilai durasi meningkat tajam diatas 2,5. Peningkatan di akhir periode menunjukkan bahwa saham BMRI semakin likuid menjelang penutupan kebijakan dibelakukannya Tax Amnesty.

Durasi saham BBRI sebelum Tax Amnesty memiliki model terbaik WACD $(0,0)$ dan selama Tax Amnesty memiliki model terbaik WACD $(1,0)$. Pemilihan model terbaik karena memiliki nilai AIC dan SBC terkecil. Karena data sebelum Tax Amnesty modelnya hanya konstanta saja maka dapat dikatakan data durasi tidak memiliki efek ACD baik EACD maupun WACD dilihat dari parameter model yang tidak signifikan. Nilai durasi taksiran yang seharusnya dapat digunakan untuk membandingkan menjadi tidak berguna.

Gambar 9 secara visual menjelaskan bahwa selama periode sebelum Tax Amnesty durasi BBNI relatif stabil disekitar 2,0 yang atinya likuiditas saham juga relatif stabil sama halnya dengan saham BBCA dan BMRI. Periode awal Tax Amnesty jarak nilai durasi semakin rendah artinya saham BBNI 
semakin tidak likuid. Saham BBNI mengalami likuiditas tertinggi pada pertengahan kebijakan Tax Amnesty berlangsung dan sempat menurun kemudian meningkat tajam menjelang penutupan Tax Amnesty.

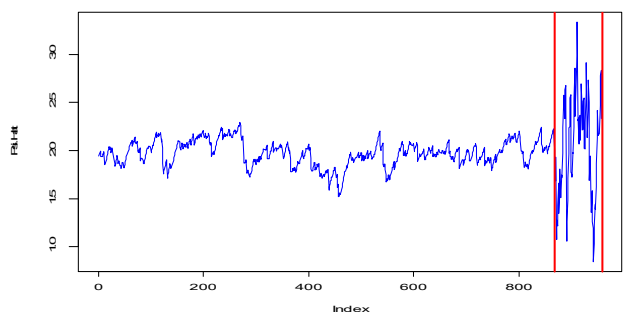

Gambar 9 Durasi Taksiran Model ACD BBNI

\section{V.KESIMPULAN DAN SARAN}

\section{A. Kesimpulan}

Hasil analisis karakteristik data dilihat dari skewness dan kurtosis volume transaksi harian saham tidak mengikuti distribusi normal. Transaksi perusahaan BBCA lebih stabil dilihat dari nilai koefisien variansi volume transaksi saham terendah. Saham yang paling tidak stabil dalam transaksi harian yaitu BBNI. Hasil analisis intervensi menjununjukan tidak terdapat efek intervensi akibat adanya kebijakan Tax Amnesty pada BBCA dan BBRI namun, terdapat efeknya pada volume saham BMRI dan BBNI serta model belum memenuhi distribusi normal. Model pembanding yaitu model ACD yang terbentuk dapat menggambarkan bahwa volume transaksi menghasilkan nilai durasi tinggi pada periode Tax Amnesty artinya saham lebih likuid selama periode Tax Amnesty. Saham BBRI tidak dapat dibandingkan karena data sebelum Tax Amnesty tidak terdapat efek ACD.

\section{B. Saran}

Data pada analisis sebaiknya menggunakan data intraday. Pengembangan metode penelitian sangat diperlukan yaitu menggunakan pendekatan distrubusi gamma atau distribusi burr, selain itu perbedaan likuiditas sebelum dan selama Tax Amnesty sebaiknya diuji secara statistik jika memungkinkan. Penaksir parameter model EACD dan WACD masih mengandung nilai negatif sehingga disarankan dilakukan penelitian lanjutan tentang optimasi numeric sehingga penaksir parameter menjadi positif sesuai dengan teori yang ada.

\section{DAFTAR PUSTAKA}

[1] Apriyani, "Menilik Saham Bank Pilihan di 2016," 16 Februari 2016. [Online]. Available: http://infobanknews.com/?s= Menilik+Saham+Bank+Pilihan+di+2016. [Accessed 3 Oktober 2016].

[2] O. J. Keuangan, Statistik Perbankan Indonesia (Indonesian Banking Statistics), Jakarta: Departemen Perizinan dan Informasi Perbankan, 2016.

[3] Indonesia-Stock-Exchange, "IDX LQ45 Februari 2016," pp. 1-187, Februari 2016

[4] M. A. de Oliveira, R. L. P. Bueno, L. S. Kotsubo and D. R. Bergmann, "Autoregressive Conditional Duration Models: An Application in the Brazilian Stock Market. Brazil : Federal
University of São Paulo," Applied Mathematical Sciences, vol. X, pp. 1573 - 1594, 2016.

[5] A. C. Islami, Peramalan Nilai Tukar Dolar Amerika Serikat terhadap Rupiah Menggunakan Intervensi dan ANFIS, Suarabaya: Institut Teknologi Sepulus Nopember, 2016.

[6] V. Napitupulu and Syahsunan, "Pengaruh Return Saham, Volume Perdagangan dan Volatilitas Harga Saham Terhadap Bid-Ask Spread pada Perusahaan yang Melakukan Stock Split di Bursa Efek Indonesia," pp. 1-10, 2012.

[7] F. Mubarokah, Analisis Pengaruh Harga Saham, Return Saham, dan Volume Perdagangan Terhadap Likuiditas Saham Pada Perusahaan Go Public yang Melakukan Stock Split di Bursa Efek Indonesia Periode Januari 2007 sampai dengan Maret, Semarang: Universitas Semarang, 2011.

[8] I. Iin and D. Mulyani, "Analisis Perbandingan Harga Saham dan Volume Perdagangan Saham Sebelum dan Sesudah Stock Split," Aset, vol. 13, no. 1, pp. 57-63, 2011.

[9] W. W. S. Wei, Time Series Analysis, New York: Addison Wesley, 2006.

[10] R. S. Tsay, An Introduction to Analysis of Financial Data with R. 1st, New Jersey: John Wiley \& Sons, Inc., 2013.

[11] D. Ruppert, Statistics and Finance An Introduction. 1st., New York : Springer Science, 2004.

[12] P. Christoffersen and D. Pelletier, Backtesting Value-at-Risk, Quebec, Canada: Faculty of Management, 2003, pp. 4-5.

LAMPIRAN

\begin{tabular}{|c|c|c|c|c|c|}
\hline Saham & Parameter & Estimasi & $\mathbf{T}_{\text {hitung }}$ & P-value & Keterangan \\
\hline \multirow{7}{*}{ BBCA } & $\phi_{1}$ & 0,38561 & 16,68 & $<0,001$ & Signifikan \\
\hline & $\phi_{2}$ & 0,11363 & 4,87 & $<0,001$ & Signifikan \\
\hline & $\phi_{5}$ & 0,06779 & 3,09 & 0,0021 & Signifikan \\
\hline & $\phi_{7}$ & 0,05579 & 2,56 & 0,0105 & Signifikan \\
\hline & $\theta_{1}$ & 0,99526 & 373,06 & $<0,001$ & Signifikan \\
\hline & $\omega_{0}$ & 0,80188 & 1,31 & 0,1920 & Tidak Signifikan \\
\hline & $\omega_{1}$ & 0,59738 & 0,97 & 0,3308 & Tidak Signifikan \\
\hline \multirow{5}{*}{ BMRI } & $\phi_{1}$ & 0,39771 & 16,03 & $<0,0001$ & Signifikan \\
\hline & $\phi_{2}$ & 0,04830 & 1,98 & 0,0481 & Signifikan \\
\hline & $\phi_{4}$ & 0,08059 & 3,47 & 0,0005 & Signifikan \\
\hline & $\theta_{1}$ & 0,95889 & 110,93 & $<0,0001$ & Signifikan \\
\hline & $\omega_{0}$ & 0,64585 & 2,54 & 0,0112 & Signifikan \\
\hline \multirow{4}{*}{ BBRI } & $\phi_{1}$ & 0,43767 & 18,60 & $<0,0001$ & Signifikan \\
\hline & $\phi_{2}$ & 0,13553 & 5,78 & $<0,0001$ & Signifikan \\
\hline & $\theta_{1}$ & 0,98016 & 196,13 & $<0,0001$ & Signifikan \\
\hline & $\omega_{0}$ & 0,16100 & 0,81 & 0,4208 & Tidak Signifikan \\
\hline \multirow{5}{*}{ BBNI } & $\phi_{1}$ & 1,23598 & 19,04 & $<0,0001$ & Signifikan \\
\hline & $\phi_{2}$ & $-0,29293$ & $-6,40$ & $<0,0001$ & Signifikan \\
\hline & $\theta_{1}$ & 1,77758 & 31,24 & $<0,0001$ & Signifikan \\
\hline & $\theta_{2}$ & $-0,78010$ & $-13,85$ & $<0,0001$ & Signifikan \\
\hline & $\omega_{0}$ & $-0,50251$ & $-2,04$ & 0,0414 & Signifikan \\
\hline
\end{tabular}

